\title{
Protocol Background Material
}

National Cancer Institute

\section{Source}

National Cancer Institute. Protocol Background Material. NCI Thesaurus. Code C142649.

Any documentation that pertains to the further understanding of a study protocol. 